\title{
Book Review: Higher Education In The Middle East And North Africa: Exploring Regional and Country-Specific Potentials
}

\author{
Alaa Abdelghaffar \\ ${ }^{1}$ Ph.D. Student at the School of Education, Loyola University Chicago, IL. United State.
}

\begin{tabular}{|c|c|}
\hline Article Info & Book Biographical Information: \\
\hline $\begin{array}{l}\text { Article history: } \\
\text { Received: } 25 \text { October } 2020 \\
\text { Revised: } 28 \text { January } 2021\end{array}$ & $\begin{array}{l}\text { Title: Higher Education in The Middle East and North Africa: Exploring } \\
\text { Regional and Country-Specific Potentials }\end{array}$ \\
\hline Accepted: 30 January 2021 & Lai, Y. M., Ahmad, A. R., \& Da Wan, C., eds(2016). Higher Education in \\
\hline $\begin{array}{l}\text { Paper Type : } \\
\text { Book Review }\end{array}$ & $\begin{array}{l}\text { The Middle East and North Africa: Exploring Regional and Country- } \\
\text { Specific Potentials. Springer. 165pp. ISBN 978-981-10-1054-5 }\end{array}$ \\
\hline & $\begin{array}{l}\text { Author of the book Review: Alaa Abdelghaffar, Ph.D. Student at the } \\
\text { School of Education, Loyola University Chicago, IL. Email address: } \\
\text { aabdelghaffar@luc.edu }\end{array}$ \\
\hline
\end{tabular}

\section{Book Review}

The present paper provides a review of the book Higher Education in The Middle East and North Africa: Exploring Regional and Country-Specific Potentials, edited by Chang Da Wan, Abdul Razak Ahmad, and Yew Meng Lai and published in 2016. The review consists of a condensed summary of each chapter followed by a critical reading of some of the authors' arguments, in terms of impartiality, consistency, and strength of evidence.

The book consists of eight chapters and aims to provide a "holistic understanding" and analysis of higher education structure and development in six countries from the Middle East and North Africa region (MENA), especially in the post-Arab Spring era (Lai et al., 2016, p.2). Chapter one outlines the introduction, objectives, and organization of the book while chapter eight is where the authors make concluding remarks on the prospects of higher education in the MENA region. In between, each chapter takes up a country of the selected six countries and analyzes its higher education system, situated within the political, socioeconomic, and legal landscape of the respective country. The countries are in the following order: The Republic of Egypt, State of Palestine, Republic of Tunisia, Islamic Republic of Iran, Republic of Libya, and lastly the Kingdom of Saudi Arabia. The selection of the countries is explained to provide a diverse representation of the MENA region: the six countries are politically, geographically, historically, economically, and linguistically diverse.

In their introductory chapter, the authors pinpoint that they adopt a "South-South perspective" in their analyses and reference to scholarly literature mostly on developing 
countries (p.2). The authors explain their adoption of this analytical framework with their academic urge to be sensitive to the localities and specific intricacies of each county that influence the operation and functionality of higher education systems. The authors also utilize a "multidimensional approach" in addressing the political, economic, and legal atmosphere that impacts higher education in each country (p.3). The chapter, then, quickly maps out the differences among countries' education systems during the colonial era and in the postindependence era. One common theme among the previously colonized countries is that education was exclusive to the rich noble socioeconomic class during colonial rule while it became free of charge to all citizens after independence.

Written by Professor Mohamed M. Radwan, chapter two addresses education in the Republic of Egypt and starts with an overview of the country's political history. Radwan draws a chronology beginning with the royal monarchy in the early 19th century with the end of the Ottoman empire until the mid-20th century with the military coup that turned the country into a socialist republic. Among the subsequent adopted socialist policies is to offer free formal education to all Egyptians. Now, Egypt has 23 public universities offering tuition-free degree programs and another 23 private, tuition-based universities whose existence was necessary for the survival of the public free higher education sector which historically has been suffering from lack of funding and resources. Both public and private universities are under the regulatory supervision of the Ministry of Higher Education under which functions the Supreme Council for Universities that is responsible for regulating policy and collaboration among public universities. Similarly, the Supreme Council for Private Universities performs the same duties but only for the private higher education sector. Included in the public higher education sector is Al Azhar University, the oldest university in modern Egypt, which offers Sunni Islamic-focused degree programs. Yet, the Central Administration of Al Azhar Institutes is an independent supervisory body for Al Azhar University, allowing it administrative autonomy. Lastly, the Supreme Council of Technical Education is the governing, supervisory body for technical education in Egypt.

In efforts to encourage international students' mobility into Egypt, Radwan argues, there was a recent abolition of the decree that historically restricted the percentage of international students to not exceed $10 \%$ of its registered students (Lai, et al., 2016). Additionally, many universities started to adopt offering Arabic language courses to non-Arabic speaking international students. The Central Administration for Foreign Students Affairs at the Ministry of Higher Education is in charge of international students' social, educational, and recreational wellbeing during their studies in Egypt. Besides, the General Administration for Missions and Academic Supervision at the Ministry of Higher Education is in charge of designing, planning, and implementing academic and professional overseas missions as part of the tertiary educational development plan. On the other hand, some public universities have operating branches in neighboring countries, such as Sudan, Chad, UAE, and Lebanon.

As a result of the national conference held in 2000 on higher education reform, a threephased national strategic plan was designed to envision a developmental reform in Egypt's 
higher education sector from 2000 to 2017. Radwan allocates sufficient space for detailing each phase of the plan within its timeline. Generally, the reform plan addressed areas of deficiencies on institutional leadership level as well as student, faculty, and staff level and the latter's need for resources and reinforced institutional infrastructure to improve quality education and learning experience for all. Lastly, in 2007 the National Authority for Quality Assurance and Accreditation of Education, an independent accrediting body of Egyptian tertiary education institutions, is the first accrediting body in the region.

Chapter three starts with an overview of the political and socio-economic landscape of the State of Palestine, followed by a discussion of the structure of the State's higher education. Being recognized by the United Nations with its sovereignty on the Gaza Strip and the West Bank, the State of Palestine has an operating higher education system despite the dominance of the Israeli occupation (p.42). The authors outline at length the divisive Intra-Palestinian political landscape, the long-lasting Arab-Israeli conflict over land sovereignty and power which officially began with the declaration of the Jewish State of Israel in 1948, and the repeatedly failing and international and local attempts to establish "permanent and peaceful resolution" of the conflict (p.45). This polarized and conflict-shaped political life worsens the economic conditions under which the Palestinians have been living, leading to exacerbated unemployment rates among Palestinian youth.

Higher Education in the two territories under the Palestinian authorities (the West Bank and the Gaza Strip) is not immune to these political and economic crises. Due to the geographical fragmentation of and between these territories, the authors argue that educational and structural compatibility of higher education systems in and among both areas is severely lacking, aside from quality, capacity, and efficiency-related issues as well. The chapter, then, provides a brief description of the types of universities currently present in those two Palestinian-run territories: governmental, public but established and run by NGOs, private established by the independent private sector and religious groups. Generally, higher education aims to preserve the national identity of the Palestinian youth born and raised under the occupation and to equip them with technical and practical skills that would help make a living, especially since the international mobility of Palestinian youth has been tightened under the occupation. Basically, all sectors of higher education are not for profit-making. Finally, the Council of Higher Education and the Ministry of Education and Higher Education are the main regulatory bodies that supervise, develop, and implement developmental plans for Palestinian higher education. Under the Ministry lies the work of the Accreditation and Quality Assurance Commission, established in 2002 and in charge of assessing and improving the quality and efficiency of the Palestinian higher education. Important to pinpoint is the authors' emphasis on the reality that no reform, policy change, or law can be issued by the Palestinian side to be implemented in either of the two territories without the permission of the Israeli occupation, thereby immense difficulty in actualizing any developmental plan in the Palestinian higher education.

The authors, the editors in addition to Zainal Amin Ayub and Russayani Ismail, started off chapter four highlighting the role of the "Jasmine Revolution" of late 2010 and early 2011 
that happened in Tunisia as part of what afterward came to be known as waves of Arab Spring revolutions, on the development of higher education in the country. According to the authors, Post-2011 Tunisia has made progress, after overthrowing a long-standing authoritarian government, towards liberal secular democracy despite the rise in political powers of the Muslim Brotherhood-affiliated party and militant Islamic fundamentalism in general. This political climate has caused a currently widespread political and social instability, which in turn destabilizes the local economy and demotivates international investment in it.

The Tunisian higher education system is argued to be among the most advanced in the MENA region. This development is partly due to the French colonial influence on the structure of higher education in Tunisia. There are 13 public universities and about 200 institutes (technical and private institutions) and the Ministry of Higher Education and Scientific research is the supervisory body on Tunisian higher education institutions. Education at public institutions is tuition-free and relies heavily on State funding. Like Egypt, expansion in higher education enrolment contributes to furthering the youth unemployment crisis in Tunisia, due to not only the lack of practical, technical, and soft skills Tunisian youth graduate with but also the incapacity of the Tunisian market economy to take in the everincreasing number of university graduates. The unsustainability and reactionary nature of reform with the absence of a comprehensive strategic vision of development is another major issue that exacerbates the declining efficiency of the Tunisian higher education system. In 2013, the National Evaluation, Quality Assurance, and Accreditation Authority was formed and is a highly centralized accrediting body whose purpose is to particularly ensure the "quality of curriculum and quality assurance of institutions" which relies on internal and external evaluation of Tunisian higher education institutions (p.78). Interesting to mention is that Tunisia enjoys a leading role in academic research in the African continent with a strong record of research history and international collaboration.

The Islamic Republic of Iran, "the global capital of Shi'ite sect of Islam", is among the most powerful countries in the MENA region for being the second-largest country in the Middle East, the world's largest supply of natural gas, and a founding member of OPEC (p.89). Chapter five begins with a comprehensive overview of the political history of Iran that started with the Iranian Islamic Revolution of 1979 that toppled monarchy and established the modern Islamic republic, leading to Iran's current state of governance with an "Islamicoriented democratic political system" (p. 88). With the moderate policies of the current president, Hassan Rouhani, advocating for academic freedom and "scientific diplomacy" and adopting a "soft-power strategy" (p.90), Iran seeks to regain international collaboration and support. Despite those efforts, there is a persistent local lack of political transparency and actual transformative change on the social level. The country also suffers locally from brutal international economic sanctions over its nuclear activity. Unemployment, underemployment, and brain drain are few examples of acute problems that the country suffers from.

The governance of Iran's higher education system stands out when compared to other countries: it is autonomous yet guided by the general strategic policies dictated by the 
Parliament. There is no major disparity in student enrolment in both public and private nonprofit universities, yet capacity and access encapsulate a major challenge to Iranian higher education. Iran's emphasis on student mobility in developing its higher education system is evident in the work of the Central Council of Scholarship in charge of designing scholarship programs for Iranian students to study abroad. This Council is part of the national roadmap set to train, develop, and educate "where local expertise is lacking" (p.99). Scientific research in Iran has a slightly unique purpose: "commercialization and product-development to promote self-sufficiency" (p.99, 100), which is explicable in reference to the economic sanctions and tightening international pressures on Iran. there are 60 public medical universities and one private, all compatible with the internationally approved scientific standards. Enrolment in these universities is rather very competitive. Lastly, the Supreme Council of the Cultural Revolution is the national supervisory board in charge of policy and planning in higher education, the Council for Higher Education Planning is in charge of approving university curricula, and finally, the Council of Supervision and Evaluation of Higher Education is in charge of quality assurance processes which are compulsory and done both internally and externally.

Chapter six begins with providing an overview of the political landscape of Libya, which for full transparency is very complicated and not easily understood by anyone who is not concerned or up to date with the current political changes happening in the region post-2011 Arab Spring uprisings, and due to the ongoing internal war in Libya. In a nutshell, being the Mediterranean richest oil country and the world's highest fifth in the per capita value of oil reserves, the authors emphasize that the political conflict was, still is, never void of international influences and political pressures to prevent the Islamist conservative party to take over Libyan's post-Gaddafi era which was "highly centralized, the dictatorial political regime" (p.110), lasted for more than four decades and was toppled by the 2011 uprising and NATO's military intervention in 2012. However, and because of the ongoing political civil conflict and insecurity, Libya's economy has been suffering a tremendous decline in foreign investment. Since 2014, Libya has been governed by two rival administrations: the secularistmoderate one elected in 2014 and the Islamist conservative administration formed in rejection of the election results. Instability has been featuring the political and security landscape of Libya, forming countless challenges against prospects of a potential democratic society: economic growth and social stability, political internal divide, and external interference, to name a few. With the absence of law and national police, local terrorism and crime rate has been on the rise leading the country to a permanent state of civil disorder and insecurity.

Libya's public higher education system, tuition-free, consists of ten universities and 109 technical institutes. Given the political transitional period the country is experiencing, the current government does not have a long-term development plan for higher education which faces a multitude of challenges: unqualified and unemployable graduates, declining infrastructure with rising enrolment rates, lack of funding for scientific research, absence of international research collaborations, and poor budgetary planning. A unique feature of Libya's higher education, note the authors, is not being entitled to expelling students who cannot get ahead in their university programs. The rationale for this feature is quite salient: 
due to the "antagonistic culture" ingrained in the subconsciousness of the Libyan people and dictates their violent response to any unfavoured policy change, the administration of universities has never been inclined to expel students who repeatedly fail courses. Interestingly, the authors elaborate that the technical and vocational institutes suffer a shortage of student enrolment due to societal motives that prefer medical and engineering degrees over vocational training. As a result of low enrolment rates, the country suffers from a shortage of local skilled labour needed for the oil and gas industry, the backbone of the country's economy. Prevalent academic corruption is another dominant feature of public higher education in Libya, evident in widespread exam cheating and "fake diploma schemes" (p.119). Unlike the private higher education sector which is required to undergo meticulous quality assurance and accreditation processes set by the National Council for Quality Assurance and Accreditation, public higher education is not at all. The National Council of Universities following the Higher Education Act 1992 is the main governing body in charge of supervising development plans for Libyan higher education, whose policies and decisions have been overthrown in the post-Gaddafi era representing a major educational governance shortfall.

In chapter seven, the authors analyze the higher education system and development in the Kingdom of Saudi Arabia, the largest country in the Middle East and the World's leader in the oil industry. Higher education is mobilized as a tool for developing a sustainable economy and producing a knowledge society through its (higher education system) internationalization, mobilization of technology, and expanding distance learning. Ruled by the Saudi Royal Family, the Islamic monarchy of Saudi Arabia is "highly authoritarian" (p.128). The authors detail out the structure of the political and judicial system in the Kingdom. With most of the powers concentrated in the hands of the King, Shari'a law is considered the country's constitution. The country enjoys a long history of domestic, regional, and global security threats and instability, especially with the rise of Islamic fundamentalist groups in the region. Yet economically and thanks to oil reserves, Saudi Arabia represents one of the strongest economies in the Arab world. However, there is a high rate of unemployment among Saudi nationals while the country's economy relies on foreign cheap labor.

Government investment in the education sector comes as part of the national strategic plan for economic development. Due to national initiatives to expand access to higher education, the government adopts a financial and structural plan to encourage the rise of the private sector by allowing for funds and scholarships that were previously exclusive to public universities. Important to mention is that gender segregation is the prevalent, culturally rooted feature of the Kingdom's higher education system. As part of the national economic development plan, KAUST is a research-intensive, gender-integrated, "experimental initiative" whose aim is to form an academic institution on Western standards and values and to attract "world-renowned" faculty and scholars to work there (p.138). Unlike Iran, the governance of Saudi Arabia's higher education sector is highly centralized under the authority of the Ministry of Higher Education. Bureaucracy, lack of transparency in communication, and pay discrimination based on nationality are a few characteristics of the 
higher education system that impede developmental plans. Yet, like Iran, the Kingdom adopts a national program (King Abdullah Foreign Scholarship Program) for fostering student mobility to Western universities to allow for intellectual, creative, and collaborative research in the service of the country's economic development goals. Unlike the other countries in the book, the private higher education sector in Saudi Arabia is fairly developed with practical training and relevant curricula to the market needs, thereby increasing the employability of its graduates. Lastly, the National Commission for Academic Accreditation and Assessment, established in 2004, is the only accrediting body and is under the supervision of the ministry of higher education yet with "administrative and financial autonomy" (p.143).

In the concluding chapter, the authors provide a cohesive summary of the main themes derived from the six comparative case study analyses provided in the book chapters. Diversity in the political, economic, and social climate among these countries is a prevalent theme that mandates being culturally and historically sensitive to the context the authors analyze. Lack of strategic efforts to maximize benefits from the economically rich resources in some of these countries is another prevalent theme and the authors spent adequate space outlining the potential efficiency of those resources to serve the development of higher education systems of these countries. Furthermore, the authors argue that the internationalization plans and processes of higher education in these countries could be more effective by focusing on academic mobility and collaboration with developed Asian nations, not only Western nations. The authors end the chapter, noting the "educational revolution" the MENA region needs alongside the political revolutions of the Arab Spring to actualize development in the higher education sector (p.154).

\section{Critical Reading}

In chapter two on Egypt, the author deviates from the general structure followed by the book chapters by adding subsections addressing gender, development, and internationalization in higher education in Egypt. Radwan justifies the consistently prevailing gender disparity to male's favour in university enrolment with the "slight disparity" in favour of women upon graduation and post-graduation employment (p.19). He argues that more women than men get employed upon graduation. This gender disparity in employment, however, is part of another phenomenon of the gender pay gap in Egypt. According to a study conducted by the World Bank, the gender pay gap is currently 22\% in Egypt (Samar, 2018). And this persistent gender gap is considered a motive for employers to hire women than men (Mohamed, 2015). So, gender disparity in employment is probably not because more women than men do graduate, unlike what Radwan believes, it is largely because women are paid less than men with the same qualifications.

Furthermore, a contestation can be held against how the author of this chapter (Dr. Mostafa M. Radwan, Professor of Mathematics and Physics at Al-Fayoum University, a public governmental university), addresses the political turmoil the country experienced in early 2011. Radwan explains that because of claims of fraudulent parliamentary elections that happened in 2010 and in which the Muslim Brotherhood, "the most organized" political oppositional party at the time, were not able to grant a single seat in the parliament-elect, 
demonstrations erupted throughout the country protesting this "vote rigging" (Lai. et al, 2016, p.13,14). Besides, there was no mention of the repeated incidents of police brutality against civilians that preceded what happened in 2011 or other economically driven motives that triggered those protests, Radwan chose "25th Jan. activities" to refer to the Egyptian youth and mass Revolution that was part of what came to be known as the Arab Spring uprisings. Protests and sit-ins that lasted for more than two weeks were due to excessive use of violence against protests, political corruption, and authoritarianism, deteriorating economic conditions of the country that led to severe impoverishment of the people (Bakr, 2016). Although Radwan acknowledges that members and leaders from the Muslim Brotherhood party later joined the 2011 protests, he does not provide historical or scholarly evidence to back his unique term up (25th Jan. activities).

However, in Radwan's description of what happened in June 2013 as a "second revolution" (Lai et al, p.14) lies an implicit acknowledgment of the historical validity of the $25^{\text {th }}$ Jan. Revolution. Similarly, calling activities of June 2013 a people's revolution while dismissing scholarly and political analyses that acknowledged it as a military coup against an elected president (Sowers \& Rutherford 2016), is another controversial claim that lacked historical back-up. Some scholars argue that what happened in June 2013 was a counter-revolution in which a military coup was performed with false public support to overthrow an elected government (2016). Moreover, there is an unwarranted claim Radwan makes in explaining the lack of local safety and rise of crime rate post-2011, that there were "unknown assailants" who attacked police officers and broke into prisons to free the prisoners and instil chaos into the country (Lai et al. 2016, p.15). This claim should not be presented in a scholarly work as an absolute historical reality without proper nullifying backed with strong historical evidence against the counter analyses of those historical moments that assert the overthrown government's influence onto, if not order of, those prison breakouts for the exact same reason of forging chaos in the country (Abouzeid, 2011). In short, I believe that being sensitive to contrasting historical narratives about decisive moments in a country's history could have added more depth and scholarly insight to Radwan's arguments.

In regard to chapter four on Tunisia, it is interesting to note the lack of inconsistency juxtaposing the authors' acknowledgment of the Jasmine Revolution as part of the 2011 Arab Spring revolution waves in opposition to Radwan's lack thereof when addressing the 25 Jan. Egyptian revolution, as elaborated above, despite the historical reality that the latter was sparked and inspired by the former Tunisian revolution. Organizationally, the authors spent a wider space to elaborate on the public motives and structural problems that sparked the Tunisian revolution and how it impacted subsequent reform on higher education. Paradoxically, Radawn argues, in affirming the high quality of higher education prior to the 25 Jan. youth revolution, that the young people who participated in the protests were able to criticize the government that lasted for more than 40 years due to the high-quality education system that led to developing their critical thinking skills. To me, this is an unwarranted selfcontradictory argument that could have been handled by the book editors. 
In chapter six, the authors expanded at length on describing many local incidents of terrorism and crime that were perpetrated by militia groups, in asserting the well-known reality that Libya has been in flux, politically, security-related, and socially, since 2011, which is an exhaustively covered topic by news outlets. Although the relevance of highlighting the country's local security situation to the structure of the book was apparent, the effort exerted on making direct connections to the ways higher education was impacted by these incidents was minimal. In fact, the authors mentioned that they conducted a short fieldtrip in Libya where they witnessed a terrorist bombing close to the University of Tripoli, yet they did not try to showcase how this high level of local insecurity and crime impacted the operation of the University given how long this situation has been. Similarly, in explaining the high rate of unemployment among Libyan youth despite the high number of foreign labor in foreignowned companies, the authors put direct blame on the Libyan formal education system for not being market-oriented or skills-oriented due to the historical lack of strategic development in the education sector. On this deficiency approach, I think the authors could have used more space making this connection clearer and more concrete, especially that it is directly related to the topic of the book. Juxtaposing this deficiency argument with the subsequent one underscoring the role of social pressures and expectations in directing student enrolment toward science schools, shows the inconsistency in the authors' explanation. Had the two factors been interrelated, the authors should have pinpointed this interrelationship more directly.

Lastly and in reference to the authors' rationale of their selection of the countries to include in the book: having a colonial past and experiencing the 2011 Arab Spring revolutions. This is true for only three of those countries: Egypt, Libya, Tunisia. Being under the Israeli occupation since 1948 after the end of the British colonization, the State of Palestine did not take part in this Arab Spring (Miller, 2019). Moreover, Neither Iran nor Saudi Arabia fulfills the first criterion of having a colonial past. And while Saudi Arabia slightly meets the second condition of having "less impactful" protests in early 2012, Iran did not experience any (Mattar, 2016, p.2). Although the authors justified their country selection to provide a diverse representation of the MENA region, they could have spent more time explaining the integration of those latter countries, especially that those criteria shaped the analyses provided in each chapter.

\section{References}

Abouzeid, R. (2011). Did prison breakout reveal a plan to sow chaos in Egypt?. Times. http://content.time.com/time/world/article/0,8599,2059301,00.html

Bakr, N. (2016). The Egyptian revolution. In S. Calleya \& M. Wohlfeld (Eds), Change \& Opportunities in the Emerging Mediterranean. Mediterranean Academy of Diplomatic Studies 
Miller, A. (2019). Why is no Arab Spring in Palestine?. Carnegie Endowment for International Peace. https://carnegieendowment.org/2019/11/13/why-no-arab-springin-palestine-pub-80329

Mattar, T. (2016). Saudi Arabia and Arab Spring: Five years of influence and action. Third Asia Pacific Conference on Advanced Research. https://apiar.org.au/wpcontent/uploads/2016/10/8_APCAR_July_BRR734_Social-Sciences-448-454.pdf

Mohamed, A. (2015). An analysis of the gender pay gap in the Egyptian labour market. IARIW-CAPMAS Special Conference "Experiences and Challenges in Measuring Income, Wealth, Poverty and Inequality in the Middle East and North Africa". http://iariw.org/egypt2015/amalkhairy.pdf

Samra, Y. (2018). Egypt's GDP could jump 32\% by achieving gender equality: IFC. Egypt Today. https://cutt.ly/JhmtCh0

Sowers, J. \& Rutherford, B. (2016). Revolution and counterrevolution in Egypt. Ch.2 in M. Haas \& D. Lesch (Eds), The Arab Spring: The Hope and Reality of the Uprisings. American Journal of Islamic Social Sciences. Westview Press. 